How to cite: Niculae, L. (2019) Environmental Impact of Mining in the Banat Mountains. 2019"Air and Water-Components of the Environment” Conference Proceedings, Cluj-Napoca, Romania, p. 365-374, DOI: 10.24193/AWC2019 36.

\title{
ENVIRONMENTAL IMPACT OF MINING IN THE BANAT MOUNTAINS
}

\author{
Lucica NICULAE $I^{I}$
}

DOI: 10.24193/AWC2019_36

\begin{abstract}
ASTRACT. The Banat is a geographical and historical space that is currently divided among three countries: the eastern part lies in western Romania, the western in northeastern Serbia and a small northern part lies within southeastern Hungary. The Banat Mountains consist of a number of mountain ranges in Romania, considered part of the Western Romanian Carpathians mountain range, which include: the Semenic Mountains, the Almăj and Locva Mountains, the Anina Mountains, and the Areniş and Dognecei Mountains and the Poiana Ruscă Mountains (Geografia României, vol. I, 1983). The Banat Mountains inherited severe environmental problems from more decades of communist rule, as their industries were heedless of environmental impacts. As result, many environmental ,hot spot" zones were created, having extreme pollution loads, environmental degradation and related human health risks. The environmental impact of mining includes erosion of relief, formation of shinkholes, loss of biodiversity, contamination of soil, goundwater, and surface water by chemicals from mining processes in particular by decommissioned enterprises. The selection of the parameters analysed in this paper aimed at identifying the areas where soil, water and air pollution pose a medium to high risk The alert signal is more obvious and it is due to the fact that projects focusing on reopening/continuing the activity of some non-ferrous ore mines have been launched lately, implying the risk that these relaunches might be done without considering the rules to be observed in view of sustainable development.
\end{abstract}

Keywords: mining, radioactive environment pollution, critical area.

\section{INTRODUCTION}

The Banat Mountains, with the exception of the northern part of Poiana Rusca Mountains, are located in Caraş-Severin County, occupying half of its surface.

Since the beginning of the millennium, Banat Mountains, alongside Apuseni Mountains have been the main exploitation source of ferrous and non-ferrous ore used in carrying out crafts specific to each historical period. Proofs of primary processing of various ore types have been dated to the Bronze Age, the Iron Age, but the first signs of this economic branch industrialisation were first noticed during the Habsburg occupation of the Romanian south-western space.

As it was an expensive resource in terms of exploitation, as well as processing, the main target at the time was the profit achieved in a very short time and as much as possible regardless of the beneficiary. Nevertheless, the negative consequences of these resources exploitation on the human habitat drew the attention and required adopting measures to protect the environment and people's lives. 
The environmental impact of mining includes erosion of relief, formation of shinkholes, loss of biodiversity, contamination of soil, groundwater, and surface water by chemicals from mining processes in particular by decommissioned enterprises. The erosion affects the exposed hillsides, main dumps, tailing dumps and change the regional drainage. In this paper are mentioned several environmental impacts, such as: water pollution, acid rock drainage, heavy metals, effects on biodiversity, vegetation and effects of mine pollution on humans. Also, many metals become mobile as water becomes more acidic and at high concentrations these metals become toxic to most life forms. The results of this study can be used by various shareholders, mainly the mining companies, local authorities and environmental organisations in order to integrate them in their post-mining measures, making them conscious by the potential long-term impact of mining on the local environment

\section{NATURAL BACKGROUND}

The natural background of Banat Mountains is made of a series of mountainous systems, such as: the Semenicu Mountains, with a maximum height of $1,447 \mathrm{~m}$ at Piatra Goznei Peak, are the highest sector of Banatu Mountains and a very important oro-hydrographical node at the same time. They have long, round ridges and wide erosion platforms. The Almăju Mountains with sinuous bridges and they reach a maximum height of 1,224 $\mathrm{m}$ at Svinecea Mare Peak. The Dognece Mountains are located in the north-west of Banat Mountains between Pogăniș Valley, to the north, and Caras Valley, to the south. The slopes are covered by forests and are aligned on the NE-SW direction. This mountainous range is cross-cut by Bârzava River in the centre, which functions as a connection corridor between Reșița and Timiș Plain. They reach maximum altitude at Culmea Mare, with a height of $617 \mathrm{~m}$. The Anina Mountains reach maximum height at Leordiș Peak, with a height of 1,160 m, and are located between Bârzava Valley, to the north, Nera Canyon, to the south, Bozovici Hills, Poneasca Valley and the upper course of Bârzava, to the east, Oravița Hills and Lupac Depression, to the west. The Locva Mountains, with the maximum height reached at Corhanul Mare Peak $(735 \mathrm{~m})$, are located in the western part of Banat Mountains, being delimited by Nera Valley, to the north, Liubcova - Șopotu Nou corridor, to the east, and the Danube, to the south and the south-west (Fig. 1).

In terms of climate, an annual average temperature of $10.5^{\circ} \mathrm{C}$ is recorded here. The absolute maximum temperature was $38.7^{\circ} \mathrm{C}$ in 4 July 2000 , while the absolute minimum temperature was $-19.2^{\circ} \mathrm{C}, 31$ January 1987 . The annual average precipitation quantity was $743.5 \mathrm{~mm}$. The annual maximum precipitation quantity was $1,101.0 \mathrm{~mm}$ in 2005 , while the annual minimum precipitation quantity was $443.0 \mathrm{~mm}$ in 2000 .

The main waters crossing Banat Mountains are: Cerna, Timiș, Bârzava, Caraș and Nera. The Danube forms the southern limit. There is a small number of natural lakes: Dracul Lake has a surface of $700 \mathrm{~m}^{2}$, the smallest carst lake, Ochiul Bei Lake has a surface of $284 \mathrm{~m}^{2}$. The Banat carst also holds underground carst lakes, formed by the underground locking of some cave tunnels, as can be seen in Plopa and Buhui caves from Anina Mountains. 
The forests fill over 400,000 ha, Caraș-Severin County ranking the second in the country from this point of view. The forests comprise types of coniferous trees, broad-leaved trees and a combination of the two types.

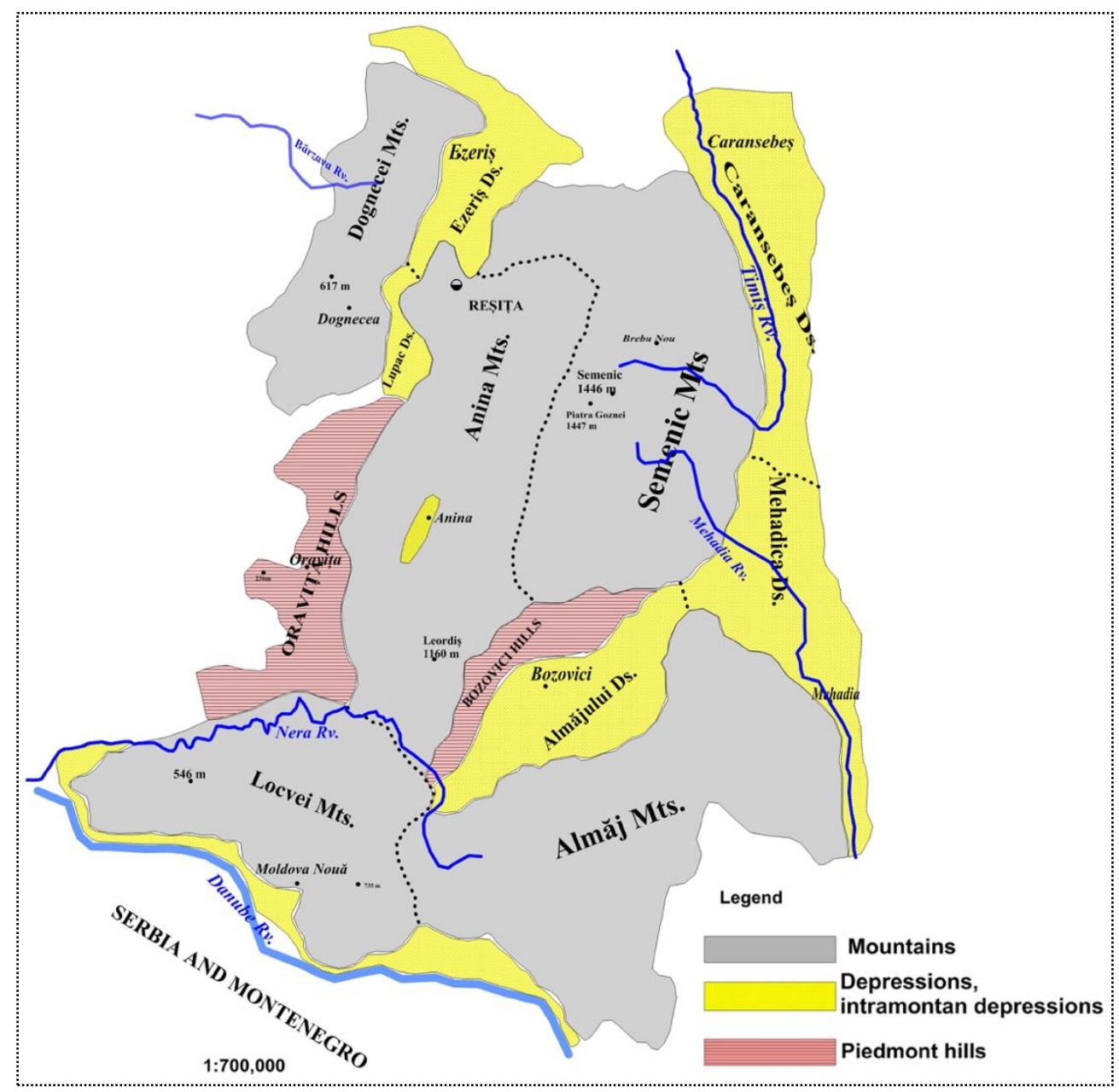

Fig. 1. Sketch of the relief units in Banat Area (simplified sketch after the physical map of Caras-Severin County, https://pe-harta.ro/caras-severin/)

The soils are disposed according to the relief, the climate conditions, the vegetation, etc. The rendzinic-argillic soils cover the largest share, of 122,939 ha, followed by cambisols, covering a surface of 101,938ha. In terms of fertility, the largest share within the category of arable lands is covered by the category III soils (in terms of quality), with a surface of $43,022 \mathrm{ha}$, followed by the category IV soils, with a surface of 40,720 ha. The category I soils cover a small surface of 1,232ha. Being a mostly mountainous area with meadows, the soils have a medium to reduced fertility, proven also by the high share of category III soils, with a surface of 103,091ha (Fig. 2). 


\section{FINDINGS}

The reduced share of higher quality soils shows that these are restricted lands due to the action of anthropogenic degradation factors (improper agricultural works, tailing dumps, waste dumps, tailings management facilities) (Fig. 3).

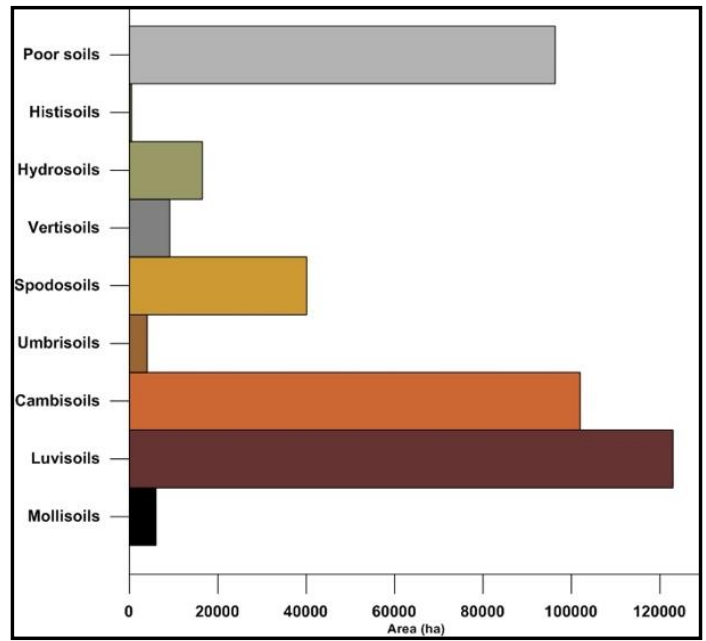

Fig. 2. Repartition of soils classes in Caras-Severin County (2005, Annual report of environment in Caraș-Severin County)

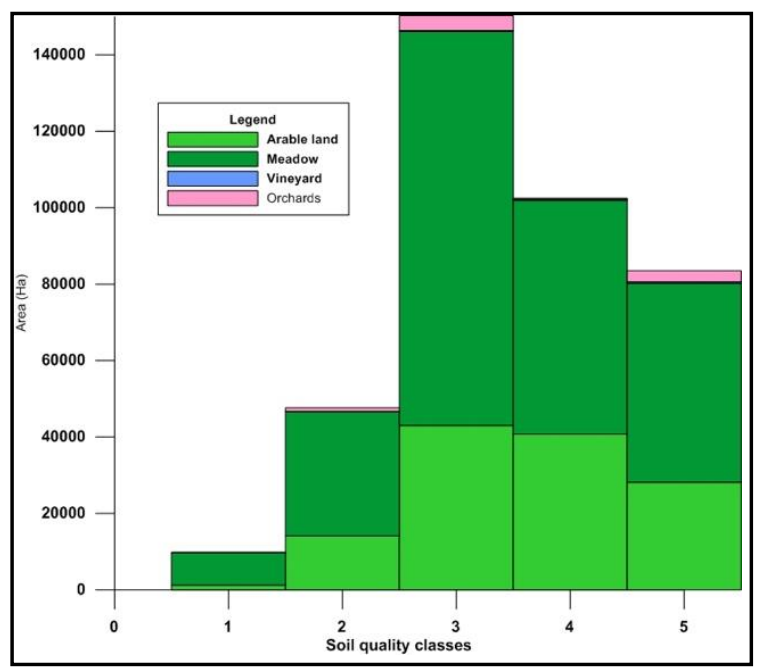

Fig. 3. Land repartition on soil quality classes in Caras-Severin County (2005, Annual report of environment in Caraș-Severin County)

A special situation is that of the polluted soils following the activities from the industrial sector (mining, steel), found in Banat Mountains, but also in the rest of Caraș-Severin County. For instance, the activity from the industrial sector 
determined the temporary removal from the economic circuit of approx. 57.3 ha of lands representing the four slag dumps located in Reșiţa and Oțelu Roșu.

The tailing dumps resulting from the mining exploitations also cover a surface of approx. 620 ha and are located in the areas with a mining tradition, such as: Moldova Nouă, Rușchița, Anina, Bocșa, Oravița (ANPM, 2005).

The tailings management facilities are an important and permanent source of soil pollution with solid deposits on considerable agricultural land surfaces located in their proximity.

The critical areas in terms of soil pollution due to mining activities are Anina, Ciudanovița, Moldova Nouă, Rușchița and Bocșa, among which Anina and Moldova Nouă cover the largest share (Fig. 4).

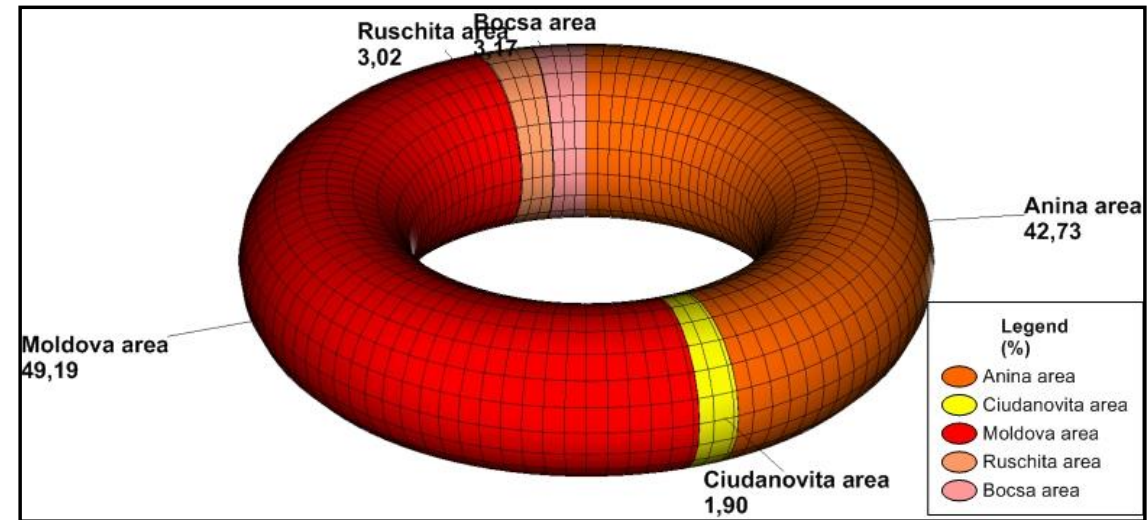

Fig. 4. The critical areas in terms of soil pollution Banat area (2005, Annual report of environment in Caraș-Severin County)

\subsection{Ferrous and nonferrous ore}

In Banat Mountains area, there are important mining exploitations, some of them have hystorical value, such as:

- Bocșa Mine from Dognecea Mountains, on Bârzava Valley, at the point called Cracul de Aur. According to some people (Macrea, 1969), iron must have been exploited here, not gold (there are proofs of exploitation dating to the Roman age). The industrial exploitation started in 1854, when the mine was taken over by the Austrian company STEG - Staatseisenbahngeselschaft.

- Ciclova Copper Mine from Anina Mountains, Caraș basin, Ciclova Valley. The copper ore was probably known during the Bronze Age or the Roman age (Maghiar, 1970, Zaberca, 1990). The systematic exploitation started after the Habsburg occupation of Banat, in 1718. The exploitation was launched in 1719. The ore was melted in a workshop in Oravița. After 1854, the Austrian company STEG modernised the activity of this mine and of others from Transylvania and Banat.

- Dognecea Gold, Silver, Copper, Lead and Iron Mine from Dognecea mountains, Dognecea Valley, tributary of Caraș. Dating since the Roman period, it was mentioned by Ignaz von Born at the end of the 18th century in his works. After 1854, 
it was taken over by the STEG consortium. It was one of the most productive mines from Banat (Codarcea, 1931, Fig. 5).

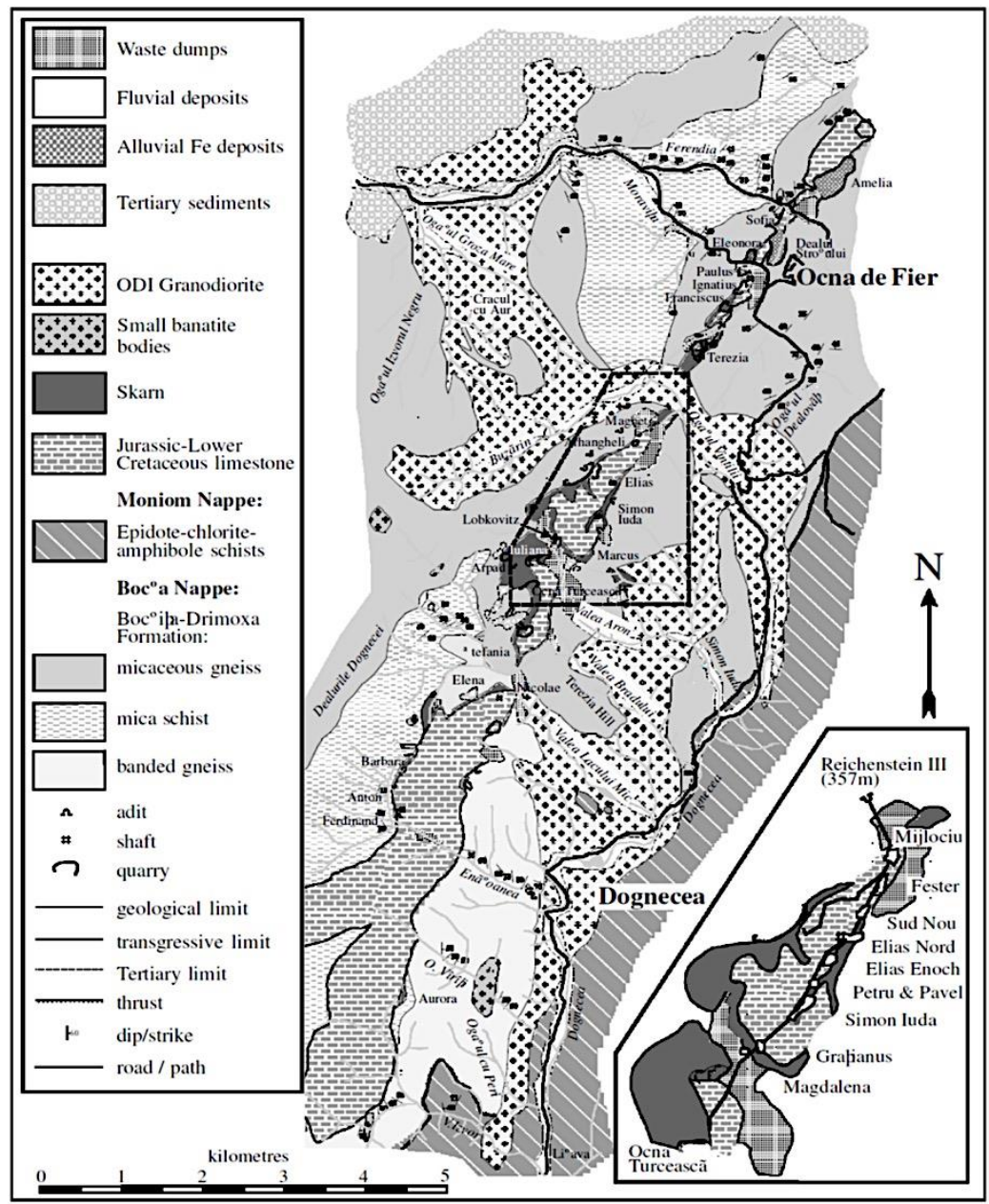

Fig. 5. Geological sketch map of the Ocna de Fier-Dognecea (after Codarcea, 1931)

- Maidan Gold Mine from Anina Mountains, Caraș basin. It dates since the Roman age.

- The gold, silver, copper, lead and iron mine from Moldova Nouă, located in Locva Mountains, Boşneag Valley, the Danube Bend. We have to mention that deposits of pyrite-double sulphide of iron and copper are still exploited in Boșneag Valley, known since the Bronze Age. Copper, iron and silver used to be exploited in the Dacian-Roman age. Like the previous mines, this was reopened after 1854. In 1869, "Florina" and "Suvarov" mines were recorded as being exploited.

- Sasca Română Gold, Copper, Lead and Iron Mine from Locva Mountains, on Nera Valley. The mine operated during the 16th-19th centuries. In the 19th century, 
new mines were opened between Sasca and Driei Sasca or Riter and Sfântul Gheorghe mines, where nickel was extracted. In 1842, Multak tunnel was opened.

- Slatina Gold Mine from Semenic Mountains, on Timiş Valley, dating since the Roman age.

- Surducu Mare Gold, Silver, Copper and Lead Mine from Dognecea mountains, Caraș Valley, tributary of Corneret.

- Iron, lead, copper, silver, gold, arsenic and antimony from Ogradena Veche, from Almăj Mountains, the Danube Valley, tributary of Mraconia.

Among the subsoil resource categories, we mention the coal resources, such as: energy pit-coal, bass, etc., or useful rocks - lime, granite, andesite, marl, etc. (according to Fig. 6).

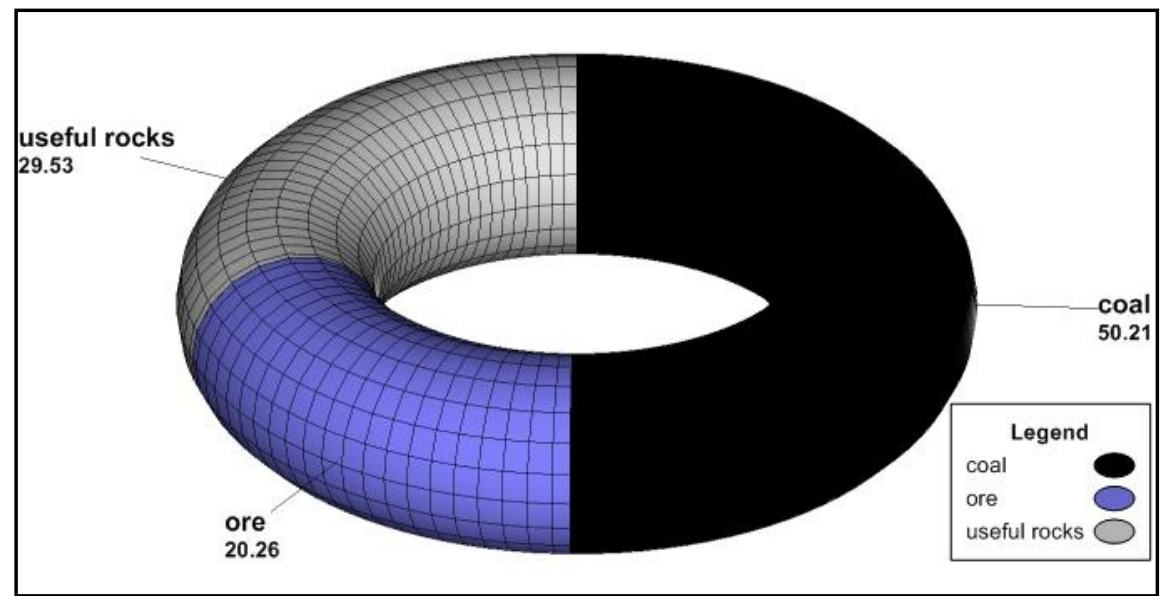

Fig. 6. Subsoil resources in Banat Area (percent) (2005, Annual report of environment in Caraș-Severin County)

\subsection{The issue of the production wastes}

Being an area with old and diverse exploitations, the issue of industrial waste treatment has been raised in the last decades. The statistical data show that only $1.89 \%$ of the waste quantity is capitalized, of which the wastes resulting from the extractive industry have a large share (97\%), (2005, Annual report of environment in Carass-Severin County) of which more than half are wastes with a metallic content. The tailing is eliminated in tailing dumps or tailing management facilities, without a prior treatment.

From an administrative point of view, the surface covered by industrial wastes in Caraș-Severin County is 713.33ha, (2005, Annual report of environment in CarașSeverin county) being formed of: tailing dumps, tailing management facilities and slag and ash dumps. (Fig. 7) 


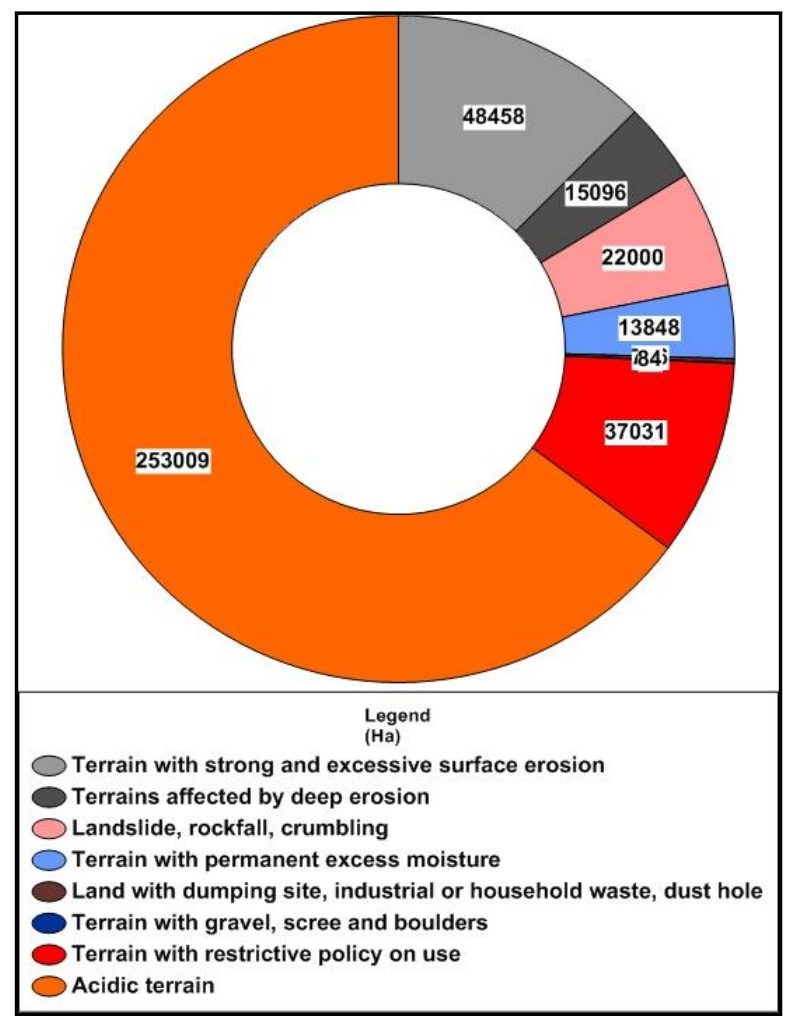

Fig. 7. Repartition of restrictive terrains in Banat area (2005, Annual report of environment in Caraș-Severin County)

\subsection{Environment protection measures in the mining spaces}

The long and intensive exploitation of natural resources, especially of the ones from the subsoil, has led to the serious environment pollution in the Banat Mountains area.

The air pollution is determined by the presence of radioactive waste dumps and uranium ore dumps, such as the ones near Ciudanovița-Lișava.

Since the finish of the $20^{\text {th }}$ century and beginning of the 21 st century, funds have been allocated and measures have been taken to protect the environment and to rehabilitate the affected areas due to the mining activities. For instance, in 2005, funds were allocated to start the closing and greening works at Lișava and Ciudanovița mines, belonging to Compania Națională a Uraniului S.A. Bucharest - Banat Oravița Branch. The tailing and poor ore dumps, as well as the mine waters and the ones washing the dumps are radioactive environment pollution sources. The works lasted for 5 years aiming to eliminate the environment pollution in the targeted area.

The recovery/removal from the natural or economic circuit of the lands with mining wastes is a process that can be viewed as temporary, but that lasts at least two generations in the meaning of the concept of "sustainable development". Hence, after 2015, the monitoring programme of the areas with the anthropogenically changed natural capital from Caraș-Severin, carried out in the area of the 
uraniferrous mining sectors of Ciudanovița and Lișava and of Mehadia Mineralisation, was launched.

The field campaigns performed in 2018 aimed mainly at identifying the environment resources from the areas affected by the mines, their evolution status and the balance/imbalance of their evolution. As a result, the authorities must consider the following objectives:

- increasing the physical and chemical stability of tailings management facilities;

- stabilising the waste dumps by levelling or changing their location, especially that of the radioactive waste dumps;

- ensuring the stability of the slopes against erosion;

- minimizing the degree of polluted water infiltration in the soil layer;

- reducing the effects generated by the acid mine water and, implicitly, reducing the areas with acid fields;

- applying biological recultivation measures (mitigation, planting grass and forestation), although nature, sometimes, makes an effort in this direction (the Suvorov case).

We also mention as immediate measures that should be taken:

- dismantling the buildings and facilities at the location of ore processing complexes;

- neutralising the surfaces used as storage facilities for the radioactive waste dumps;

- stabilising the land of tailings management facilities, the tailings dumps, the slopes, stopping flood evolution.

\section{CONCLUSION}

Banat Mountains is one of the richest areas in natural soil and subsoil resources. These resources were mostly exploited without considering the protection of the environment. Thus, measures are required in the near future regarding the protection of natural elements and new resources should be found that have a renewable nature and do not pollute.

Regarding the forwarding of funds towards opening/reopening some ore mines, the principles of sustainable development must be considered.

According to some, the extension of the mine life cycle by remining offers the possibility for sustainable development in the area. Remining represents an extension of the mine life cycle, period that contributes to the achievement of sustainable development objectives and that slows down the transition to closure, preparing the local community and economy at the same time. Thus, social and environmental shocks can be avoided and the risks associated to the closure and the remedy of the location are much reduced.

The failure to comply with this principle has led to the consequences we face nowadays, which shall be reflected in the lives of future generations as well. 


\section{REFERENCES}

1. Codarcea, Al. (1931), Ètude géologique et pétrographique de la région Ocna de Fier-Bocșa Montană, Roumanie, An. Inst. Geol. Rom., 15: 261-424.

2. Macrea, M. (1969), Viața în Dacia Romana, București, p.302.

3. Maghiar, N., Olteanu, Ș. (1970), Din istoria mineritului în România, București, p.53, $56,70,87,186,193$.

4. Zaberca, V., Graf, R. (1990), Informații despre mineritul și metalurgia bănățeană de la mijlocul veacului XIX-lea, Banatica 10, 1990, p.297.

5. ANPM (2005), Annual report of environment in Caraș-Severin county,

6. $\quad * *^{*}(1983)$, Geografia României, vol. I, Edit. Academiei, București 